that they possessed a clear perception of the most effectual means of raising and advancing their fallen country; they read aright the lessons of the recent war, and declared that Science alone, in its widest acceptance, could be the saviour and elevator of France. And, indeed, there is the greatest hope of a country that has produced men, and that in so great numbers, capable of doing the work the results of which are chronicled in the handsome volume before us; for we are persuaded that this first volume of the French Association's Proceedings will compare favourably with any single volume of the Proceedings of the British Association. The meeting last year at Lyons fully bore out the promise of the first meeting, and we have no doubt that this year's meeting at Lille will be at least equally successful. Let the members of the Association only do all in their power to keep up its high character and carry out faithfully its declared objects, and the beneficial results of its establishment both to Science and to France will, ere long, be evident. As it is, partly no doubt owing to the work of the Association, Science since the conclusion of the Franco-Prussian war has taken immense strides in France; everything taken into consideration, the amount of scientific activity which has recently been developed in that country is very wonderful, and calculated to call forth the gratitude of the friends of science and humanity.

\section{NORTH AMERICAN BIRDS}

A History of North American Birds. By S. F. Baird, 'T. M. Brewer, and R. Ridgway. Vols. i, ii. and iii. Land Birds. (Little, Brown and Co., I 874.)

r $\mathrm{HE}$ ornithologists of the United States appear to be not less active than those of this country at the present moment. Whilst here we have Gould's "Birds of Great Britain," Dresser's "Bircs of Europe," and Newton's new edition of "Yarrell," all appearing at the same time, so in America Coues's "Key" and Cooper's "Birds of California" are quickly followed by the present important work on the whole of the North American Ornis. For this undertaking Prof. Baird, the well-known AssistantSecretary of the Smithsonian Institution, has obtained the assistance of two very efficient coadjutors, Dr. T. M. Brewer, of Boston, and Mr. Ridgway, already well known for his accurate work in ornithology.

The object of the present work, which aims at a wider grasp than any of its predecessors, is to give an account of what is known of the birds, not of the United States only, but of the whole of the Continent of North America north of the Mexican boundary. Greenland is included on the one side, and the newly acquired United States territory of Alaska on the other, so that many European and Asiatic forms, which have been lately discovered in these two countries, are now for the first time added to the American list.

The materials upon which this undertaking is principally based consist of the very extensive collections of birds from every part of the New World, in the Smithsonian Museum at Washington. The numerous expeditions for exploration and survey sent out of recent years by the Government of the United States into nearly every portion of their enormous western domain have been invariably accompanied by one or more collectors whose contributions have all been deposited in the stores of the Smithsonian Institution. But besides their collections these investigating naturalists have reaped a rich harvest of facts concerning the life-history of the creatures they have collected, and have deposited their records and journals also in the Smithsonian Archives. From these manuscripts, particularly from the notes of the late Mr. Robert Kennicott, who made most extensive explorations in Western America and in the most northern portion of the Hudsons Bay Territory, many of the most novel facts recorded in the present work have been drawn.

The special value of the researches of Mr. Kennicott and his fellow-workers in the north-west lies in the fact that a large number of the rapacious birds and waterfowl of North America resort in summer to these thinlypopulated districts for the purpose of breeding. Their haunts, not having been previously invaded, much novel information on the nesting habits of the members of these two groups is for the first time published in this work.

Besides Messrs. Baird, Ridgway, and Brewer, whose names appear on the title-page, we are informed in the preface that two other well-known American naturalists have contributed to the present work-Prof. Gill having furnished a portion of the introduction, and Dr. Coures the tables of the orders and families.

The work is profusely illustrated by woodcuts, besides containing a series of illustrations of the heads of all the species, drawn upon separate plates. The woodcuts contain the outlines of the principal characters of every genus, embracing the shape of the bill as seen from above and from the side, the comparative lengthis of the wing and tail feathers, and the outline of the tarsus and toes; besides reduced but well-executed and highly-characteristic whole figures of many of the species.

The tendency of the American ornithologists of late years has been rather to unduly augment the number of species by raising slight local variations in form and structure to specific rank. In the present work rather the opposite tendency is manifested, and we are not sure that it is not in some instances carried too far. For instance, the whole of the Purple Martins, of the genus Progne, recently divided by Prof. Baird into seven or eight species, are now treated of as one; and the different species of Redpole Linnets of Dr. Coues are again reduced to their primitive number. As, however, the distinctive characters, such as they are, are invariably stated with accuracy and precision, it does not really make much difference whether the forms are actually classed as species or varieties.

The three volumes of this elaborate work now before us contain the whole of the Land Birds. A fourth volume, shortly to be issued and to be devoted to the Water Birds, will complete the undertaking. There can be no doubt, as will be at once apparent to anyone who consults the work, that it is of a most complete and exhaustive character, and that it will fully sustain the well-known reputation of Prof. Baird and his fellow-labourers.

\section{OUR BOOK SHELF}

Our Common Insects. By A. S. Packard, jun. (Naturalist's Agency, Salem, Mass.)

IN this fully illustrated little work Mr. Packard, the author of the excellent and much larger "Guide to the 